\title{
Clozapine-induced acute interstitial nephritis
}

\author{
SY Chan *, CY Cheung, PT Chan, KF Chau
}

\section{A B S T R A C T}

Acute interstitial nephritis is a common cause of acute kidney injury. Acute interstitial nephritis is most commonly induced by drug although the cause may also be infective, autoimmune, or idiopathic. Although eosinophilia and eosinophiluria may help identify this disease entity, the gold standard for diagnosis remains renal biopsy. Prompt diagnosis is important because discontinuation of the culprit drugs can reduce further kidney injury. We present a patient with an underlying psychiatric disorder who was subsequently diagnosed with clozapine-induced acute interstitial nephritis. Monitoring of renal function during clozapine therapy is recommended for early recognition of this rare side-effect.

Hong Kong Med J 2015;21:372-4
DOI: 10.12809/hkmj144312

${ }^{1}$ SY Chan *, MRCP (UK), FHKCP

${ }^{1}$ CY Cheung, PhD, FHKCP

${ }^{2}$ PT Chan, MB, BS, FHKCPath

${ }^{1}$ KF Chau, FHKCP, FRCP (Lond)

1 Department of Medicine

${ }^{2}$ Department of Pathology

Queen Elizabeth Hospital, Jordan, Hong Kong

* Corresponding author: helenchansy@gmail.com

\section{Case report}

A 29-year-old woman with a known history of bipolar affective disorder and paranoid schizophrenia admitted to our hospital because of relapse of psychiatric symptoms in June 2011. She had no significant medical illness. Her medication included quetiapine fumarate and sodium valproate but was changed to haloperidol decanoate depot injection, trihexyphenidyl, and clozapine following hospitalisation. Clozapine was commenced at $50 \mathrm{mg}$ once per day and gradually stepped up to $400 \mathrm{mg}$ once per day. One week later she developed fever but had no respiratory or urinary symptoms. She remained conscious and alert with stable vital signs. Physical examination revealed no significant abnormality and preliminary investigations showed normochromic and normocytic anaemia with haemoglobin level of $87 \mathrm{~g} / \mathrm{L}$, white cell count of $11.8 \times 10^{9} / \mathrm{L}$ (eosinophils $15.1 \%$; absolute count $\left.2.3 \times 10^{9} / \mathrm{L}\right)$, and serum creatinine of $229 \mu \mathrm{mol} / \mathrm{L}$ (baseline serum creatinine 1 week ago, $39 \mu \mathrm{mol} / \mathrm{L})$. Her liver enzymes, lactate dehydrogenase, and haptoglobin were all within normal range. Chest radiograph showed clear lung fields. She was empirically given amoxicillin/ clavulanic acid but treatment was complicated by gastro-intestinal side-effects such as vomiting and diarrhoea. The antibiotics were stopped immediately and the symptoms subsided. Clozapine was further titrated up to $700 \mathrm{mg}$ once per day with consequent improvement in her mental state. Nonetheless, fever persisted with further deterioration in renal function (serum creatinine rose to $356 \mu \mathrm{mol} / \mathrm{L}$ ). Autoimmune markers including anti-nuclear antibody, anti-neutrophil cytoplasmic antibodies, and anti-glomerular basement membrane antibody were all within normal range. Urinalysis revealed the presence of red blood cells and eosinophils but urine culture showed no bacterial growth. The 24-hour urine protein was $1.18 \mathrm{~g}$. Ultrasound of the urinary system showed normal-sized kidneys with no hydronephrosis. Ultrasound-guided renal biopsy was performed and the histology showed features of tubulointerstitial nephritis with eosinophil-rich interstitial infiltrates and occasional granulomas (Fig). The likely diagnosis was drug-induced acute interstitial nephritis (AIN). Clozapine was withheld, fever subsided afterwards and renal function gradually returned to normal 4 weeks following cessation of clozapine.

\section{Discussion}

Drug-induced AIN is not uncommon. Common nephrotoxic drugs include non-steroidal antiinflammatory drugs (NSAIDs) and antibiotics such as aminoglycosides and vancomycin. Although amoxicillin/clavulanic acid remains a possible culprit in this case for AIN, the short duration of amoxicillin/ clavulanic acid use and sequence of events are more suggestive of clozapine-induced AIN.

Acute interstitial nephritis is defined as an immune-mediated condition characterised by the presence of inflammation and oedema in the tubulointerstitium of the kidneys. It accounts for $15 \%$ to $27 \%$ of biopsy-proven acute kidney injury. Acute interstitial nephritis is most commonly drug-induced although the cause may also be infective, autoimmune, or idiopathic. ${ }^{1-5}$ The classic triad-fever, skin rash, and eosinophilia-is only 
present in $5 \%$ to $10 \%$ of patients with $\mathrm{AIN}^{2-5}$ As a result, a high level of clinical suspicion is essential since around $40 \%$ of patients with AIN eventually required dialysis. ${ }^{2}$ A detailed drug history, especially herbal medicine which is common in our locality, recreational drugs and radio-contrast, are important for diagnosis. Other history including water exposure and animal contact (pets or stray animals) can help exclude or confirm several infective causes such as Legionnaires' disease and leptospirosis. Systemic manifestations of vasculitis should also be specifically looked for during physical examination.

There are no specific signs and symptoms to differentiate drug-induced AIN from other causes of AIN. Fever is present in around 30\% of patients with drug-induced $\mathrm{AIN}^{3,5}$ and it typically occurs within 2 weeks of initiation of a new drug. ${ }^{3}$ Skin rash, usually of morbilliform or maculopapular appearance, is found in only $15 \%$ to $50 \%$ of patients, depending on the type of medication. ${ }^{3,5}$ One retrospective review showed that around $45 \%$ of patients have arthralgia, and $15 \%$ and $21 \%$ of patients have dysuria and loin pain, respectively. ${ }^{5}$ Eosinophilia is thought to have great diagnostic value in drug-induced AIN as it signifies a hypersensitivity reaction although the degree and frequency of eosinophilia vary with different medications. ${ }^{4}$ Methicillin-induced AIN is associated with eosinophilia in $80 \%$ of cases while AIN due to NSAID is less commonly associated with eosinophilia, which is only around $35 \%$ of cases. ${ }^{4}$ However, the presence of eosinophilia can also be found in infections, especially those caused by helminths, allergic diseases such as asthma and eczema, and even malignant conditions such as lymphoma and carcinoma of the colon. Like eosinophilia, the presence of eosinophiluria is neither sensitive nor specific for drug-induced AIN. The sensitivity ranges from $63 \%$ to $91 \%$, and specificity from $52 \%$ to $94 \%{ }^{3,4}$ Other conditions such as lower urinary tract infection, pyelonephritis, prostatitis, acute tubular necrosis, glomerulonephritis, and urinary schistosomiasis can also result in eosinophiluria. $^{3}$ Other parameters from urine samples may also provide clues for drug-induced AIN. Proteinuria is present in $93 \%$ of patients but only $2.5 \%$ have a nephrotic range of proteinuria. ${ }^{2}$ Haematuria is usually microscopic and is present in $60 \%$ to $80 \%$ of cases while gross haematuria is only present in $5 \%$ of patients. $^{2}$ Renal biopsy can confirm the diagnosis of AIN by demonstrating inflammation and oedema of the renal interstitium and tubulitis. ${ }^{2-5}$ The presence of a considerable number of eosinophils in the interstitium will point to a diagnosis of druginduced AIN, while an abundance of neutrophils is suggestive of an infective cause. ${ }^{3}$

As drug-induced AIN is idiosyncratic and not dose-dependent, the mainstay of treatment is cessation of the causative agents. Nonetheless, not

\section{氯氮平引起的急性間質性腎炎 \\ 陳淑櫻、張志遠、陳柏滔、周嘉歡}

急性間質性腎炎是急性腎損傷常見的病因。急性間質性腎炎普遍由藥 物引起, 亦可能因為感染、自身免疫性疾病或特發性出現。雖然咾酸 性粒細胞和嗜酸細胞尿可以幫助識別這種疾病, 診斷的黃金標準仍然 是腎活檢。停止服用致病藥物可進一步減低腎損傷, 所以及時診斷非 常重要。本文報告一名精神病患者因服用氯氮平引致急性間質性腎炎 的病例。建議在服用氯氮平期間, 定期為病人進行腎功能監測, 以便 能夠及早識別這種藥物罕見的副作用。

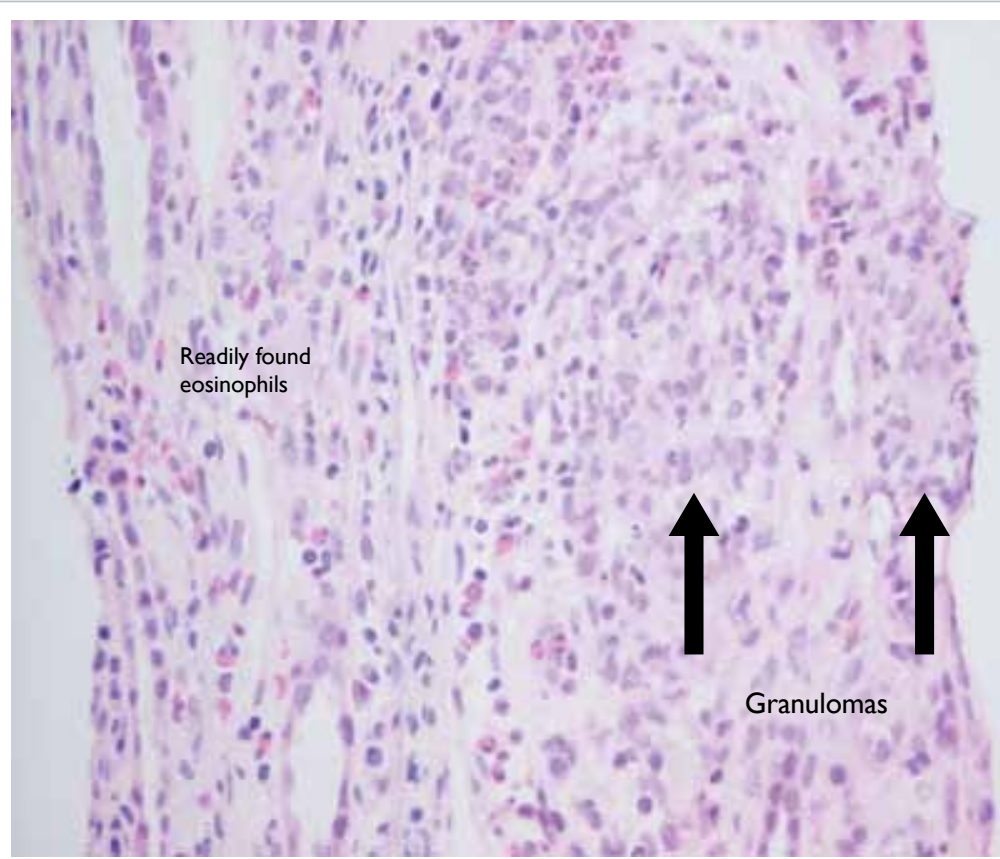

FIG. Histology of renal tissue showing eosinophil-rich interstitial infiltrates and occasional granulomas (arrows) [H\&E; original magnification, $x$ 200]

all patients experience complete recovery despite withdrawal of the index medication. Neither the severity of renal failure, the extent of interstitial involvement (including fibrosis), nor the severity of tubulitis predicts the clinical outcome..$^{2-5}$ More established prognostic factors are the duration of renal failure and creatinine level 6 to 8 weeks after diagnosis. ${ }^{4}$ Some studies advocate the use of corticosteroid to hasten recovery and prevent progression to chronic kidney disease ${ }^{6}$ but these studies have usually been small and retrospective. ${ }^{2-4}$

Since 1999, 10 cases of clozapine-induced AIN have been described. ${ }^{6-8}$ Among these patients, the ages ranged from 24 to 69 years, and six were male. 
In patients who presented within 2 weeks of commencing clozapine, $80 \%$ exhibited a hypersensitivity reaction. In those who presented late, symptoms developed up to 3 months after starting clozapine. Fever was present in $80 \%$ but, surprisingly, none reported skin rash or arthralgia. Proteinuria was detected in $80 \%$ of cases, but only four patients had red blood cells in the urine. Eosinophilia was present in half of the patients only. Four patients had the diagnosis of AIN confirmed by histology. A phenomenon is observed wherein the effect of clozapine on the kidney can be potentiated by the concomitant use of antibiotics, especially those that are known to have higher risks of interstitial damage, such as the penicillin derivatives. ${ }^{6}$ In our patient, the temporal relationship between the initiation of clozapine and the development of acute kidney injury matched the time frame described in the literature. In addition, the presence of fever, eosinophilia, and eosinophiluria also raised the possibility of clozapine-induced AIN, subsequently confirmed by histology. The renal function of our patient also improved spontaneously after removing the index medication.

In conclusion, this case highlights the rare but important potential side-effect of clozapine.
In addition to monitoring cell counts, regular monitoring of renal function is recommended after initiation of clozapine. Early involvement of nephrologists can provide early recognition of this entity with prompt investigation and treatment.

\section{References}

1. Bellomo R, Kellum JA, Ronco C. Acute kidney injury. Lancet 2012;380:756-66.

2. Praga M, González E. Acute interstitial nephritis. Kidney Int 2010;77:956-61.

3. Perazella MA, Markowitz GS. Drug-induced acute interstitial nephritis. Nat Rev Nephrol 2010;6:461-70.

4. Rossert J. Drug-induced acute interstitial nephritis. Kidney Int 2001;60:804-17.

5. Clarkson MR, Giblin L, O'Connell FP, et al. Acute interstitial nephritis: clinical features and response to corticosteroid therapy. Nephrol Dial Transplant 2004;19:2778-83.

6. Kanofsky JD, Woesner ME, Harris AZ, Kelleher JP, Gittens $\mathrm{K}$, Jerschow E. A case of acute renal failure in a patient recently treated with clozapine and a review of previously reported cases. Prim Care Companion CNS Disord 2011;13:PCC.10br01091.

7. An NY, Lee J, Noh JS. A case of clozapine induced acute renal failure. Psychiatry Investig 2013;10:92-4.

8. Mohan T, Chua J, Kartika J, Bastiampillai T, Dhillon R. Clozapine-induced nephritis and monitoring implications. Aust N Z J Psychiatry 2013;47:586-7. 